\title{
Rhinovirus-Induced Mucin Gene Expression in Airway Epithelial Cells
}

\author{
Yong Ju Jang, Hyun Ja Kwon, Jong Whan Wang, Bong-Jae Lee and Yoo-Sam Chung \\ Department of Otolaryngology, Asan Medical Center, University of Ulsan College of Medicine, Seoul, Korea
}

\section{기도상피세포에서 Rhinovirus에 의한 점액유전자 발현}

장용주 · 권현자 · 왕종환 · 이봉재 · 정유삼

울산대학교 의과대학 서울아산병원 이비인후과학교실

\author{
Received January 28, 2009 \\ Revised June 29, 2009 \\ Accepted July 7, 2009 \\ Address for correspondence \\ Yoo-Sam Chung, MD \\ Department of Otolaryngology, \\ Asan Medical Center, \\ University of Ulsan \\ College of Medicine, \\ 388-1 Pungnap 2-dong \\ Songpa-gu, Seoul 138-736, Korea \\ Tel $+82-2-3010-3710$ \\ Fax +82-2-489-2773 \\ E-mail yschung@amc.seoul.kr
}

Background and Objectives It is unclear whether rhinovirus infections promote mucus secretion in airway epithelial cells. Increase of mucin gene expression and mucin production is associated with mucus hypersecretion. We therefore investigated the effect of rhinovirus infection on mucin gene expression in airway epithelial cells.

Materials and Method The effect of rhinovirus-16 infection on the gene expression of MUC5AC, MUC5B, MUC6, MUC7, and MUC8 was evaluated using semi-quantitative reverse transcription polymerase chain reaction in A549 cells.

Results Rhinovirus significantly increased MUC5AC, MUC7, and MUC8 messenger ribonucleic acid (mRNA) expressions in A549 cells, but it did not significantly affect the expression of MUC5B and MUC6 mRNA.

Conclusion This results show that rhinovirus may induce mucus secretion in airway epithelial cells.

Korean J Otorhinolaryngol-Head Neck Surg 2009;52:670-3

Key Words Mucin · Rhinovirus · A549 cells · Airway epithelial cells.
서 론

Rhinovirus는 감기를 일으키는 바이러스로 알려져 있고 상기도 감염을 주로 일으키나 하기도에도 감염되어 천식을 악화시키기도 하며, ${ }^{1)}$ rhinovirus에 의한 선행감염으로 인해 급성 세균성 부비동염으로 진행이 되기도 한다. ${ }^{2)}$ Rhinovirus에 감염된 기도상피세포는 다양한 염증매개물질들을 내 어 기도염증과 폐색을 일으키거나 강화할 수 있다. ${ }^{1)}$ Rhinovirus가 천식을 악화시키는 정확한 기전은 아직 알려져 있지 않으나 kinin이나 histamine 등의 염증매개물질을 증 가시키고 기도점막과 점막하에 중성구, 임파구, 호산구 등 의 염증세포들을 침윤시키며 기도상피세포 등으로 하여금 다양한 interleukin들과 granulocyte macrophage colonystimulating factor, regulated upon activation, normal Tcell expressed and secreted 등을 생성하게 하고 intra- cellular adhesion molecule-1의 발현을 증가시킨다. ${ }^{1)}$ 또 한 초기에는 주로 혈장성분의 분비물을 발생시키나 후기에 는 점도가 높은 mucus를 생성시켜 기도를 폐쇄할 가능성 이 제기되었다. ${ }^{3)}$ 한편, 사람의 코에서 rhinovirus는 초기에 는 수양성 비루를 일으키나 후기에는 mucus의 분비를 증 가시킨다. ${ }^{4)}$

Mucus는 염증반응이나 환경인자로 인해 과분비될 수 있 고 ${ }^{5)}$ 과분비가 지속되는 경우 천식, 만성폐쇄성폐질환 등을 일으킬 수 있다. Mucin glycoprotein은 기도의 점액에 점 도와 탄성을 생기게 하고 ${ }^{6)}$ 점액의 주된 고분자이기 때문에 ${ }^{6)}$ 점액유전자의 발현이 증가하고 mucin이 증가하는 것은 점 액 과분비와 동반된다고 생각된다. 현재까지 알려진 기도상 피에서 발현하는 점액유전자는 MUC1, MUC2, MUC4, $\mathrm{MUC5B}, \mathrm{MUC5AC}, \mathrm{MUC7}, \mathrm{MUC8}$ 등이 있다. ${ }^{7)}$ 그 중 $\mathrm{MUC5AC}$ 는 기관지천식과 정상인에서 기도분비물 중 주성 
분으로 ${ }^{7)} \mathrm{MUC1}$ 이나 MUC2보다 비용조직, ${ }^{8)}$ 비갑개, ${ }^{9)}$ 기관 상피세포 ${ }^{10)}$ 에서 발현이 증가되어 있다.

A549 세포주는 폐암조직에서 배양한 세포로 mucin 유전 자발현과 단백연구에 적합하다. ${ }^{11}$

그러나 rhinovirus 감염이 기도상피세포에서 Mucin messenger ribonucleic acid(mRNA) 발현에 미치는 영향에 대해서는 잘 알려지지 않았다. 저자들은 rhinovirus 감염이 기도상피세포에서 Mucin mRNA 발현에 미치는 영향에 대 해 연구하고자 하였다.

\section{재료 및 방법}

\section{바이러스}

Rhinovirus-16(ATCC, Manassas, VA)은 PBS로 희 석하여 $-70^{\circ} \mathrm{C}$ 냉동고에 실험 시까지 보관하였다. 본 연구를 위해서 주요 군에 속하고 가장 흔하게 실험에 사용되는 serotype으로 rhinovirus-16을 사용하였다.

\section{세포의 배양}

A549 세포(alveolar epithelial type II respiratory cells, ATCC, Rockville, MD)는 10\% fetal bovine serum(FBS) (Hyclone Laboratory, Logan, UT)이 포함된 10\% Dulbecco's Modified Eagle Medium: Nutrient Mixture F12 Kaighn's Modification(DMEM/F-12K)를 기존 배양 액으로 하여 배양하였다. 바이러스 역가의 측정에 사용된 $\mathrm{MRC}-5$ 세포(human fetal lung fibroblast, ATCC, Rockville, MD) 는 $2 \mathrm{mM} \mathrm{L}$-glutamine, $20 \mathrm{mM} \mathrm{HEPES,} 100$ units $/ \mathrm{mL}$ penicillin, $100 \mu \mathrm{g} / \mathrm{mL}$ streptomycin, $0.25 \mu$ $\mathrm{g} / \mathrm{mL}$ fungizone을 포함하는 minimum essential media (MEM) (Gibco, Grand Island, NY)를 기본 배양액으로 하 여 $10 \% \mathrm{FBS}$ 을 첨가하여 $95 \%$ 의 공기, $5 \%$ 이산화탄소, $37^{\circ} \mathrm{C}$ 의 항온, 항습 조건에서 배양하였다.

\section{A549 세포에 대한 rhinovirus-16 감염}

실험군은 A549 세포에 배양액만 처리된 대조군, 대조군 에 rhinovirus-16을 감염시킨 감염군, 대조군에 inactivated rhinovirus -16 을 감염시킨 불활성군의 3 개의 군으로 나눴다. 각 실험군에서 A549 세포를 6 well plates에 한 well당 $5 \times 105$ 의 수가 되도록 분주하고 $10 \% \mathrm{DMEM} / \mathrm{F}-$ $12 \mathrm{~K}$ 배양액 $2 \mathrm{~mL}$ 를 넣고 배양하였다. 대조군은 $\mathrm{A} 549$ 세포를 $10 \% \mathrm{DMEM} / \mathrm{F}-12 \mathrm{~K}$ 에서 28 시간 동안 배양하였 다. 감염군에서는 rhinovirus을 $1 \mathrm{MOI}$ (multiplicity of infection)로 4시간 감염 시킨 후 PBS로 세척하여 rhinovi- rus을 제거하고 24 시간 동안 배양하였다. 불활성군에서는 $\mathrm{UV}$ 로 inactivated시킨 rhinovirus을 $1 \mathrm{MOI}$ 로 4시간 동 안 처치하고 PBS로 세척하여 rhinovirus을 제거하고 24 시간 동안 배양하였다. 각 군에서 $\mathrm{MUC} 5 \mathrm{AC}, 5 \mathrm{~B}, 6,7,8$ 에 대한 reverse transcription polymerase chain reaction (RT-PCR)을 시행하였다. 각 군의 실험은 5 회 반복하였다.

\section{RNA isolation}

각각의 실험 부유물 $200 \mu \mathrm{L}$ 에 Trizol(Life Technologie, Grand Island, NY) 용액 $1 \mathrm{~mL}$ 씩을 첨가하고 15초간 vortex를 한 후 chloroform $200 \mu \mathrm{L}$ 를 첨가하여 충분히 혼합한 후 $4^{\circ} \mathrm{C} 15,000 \mathrm{rpm}$ 으로 15 분간 원심분리하여 상 층에 있는 RNA 부유액을 채취하였다. 얻어낸 부유액을 동 량의 isopropanol로 처리한 후 동일조건으로 원심분리하여 $\mathrm{RNA}$ 침전물을 얻었고 $75 \%$ ethanol로 세척한 후 $0.1 \%$ dicthyl pyrocarbonate 희석 증류수에 용해시켰다. 용해 된 RNA의 농도와 순도를 확인하기 위해 spectrophotometer (Molecular Devices, Menlo Park, CA)로 $260 \mathrm{~nm}$ 및 $280 \mathrm{~nm}$ 에서의 optical density를 측정하였다.

\section{Mucin gene mRNA 검출을 위한 RT-PCR}

총 RNA를 Tri-Reagent (Molecular Research Center, Cincinnati, $\mathrm{OH}$ )를 이용하여 추출하였고 MUC5AC mRNA 는 RT-PCR 방법을 이용하여 측정하였다. 총 mRNA를 무 작위 hexanucleotide primer들과 Moloney murine leukemia virus (MMLV) reverse transcriptase (Perkin Elmer, Morrisville, $\mathrm{NC}$ )를 사용하여 cDNA로 역전사하였다. RT$\mathrm{PCR}$ 에 사용한 oligonucleotide primer는 Table 1 과 같다. $\mathrm{PCR}$ 은 초기가열 $95^{\circ} \mathrm{C}$ 에서 5 분 후 $\mathrm{MUC} 5 \mathrm{AC}$ 의 경우 $94^{\circ} \mathrm{C}$ 에서 30 초, $60^{\circ} \mathrm{C}$ 에서 1 분, $72^{\circ} \mathrm{C}$ 에서 1 분간을 30 회, MUC5B

\begin{tabular}{|c|c|}
\hline Gene name & Primer sequence \\
\hline MUC5AC & $\begin{array}{l}\text { 5'-TCCGGCCTCATCTTCTCC-3' (forward) } \\
\text { 5'-ACTTGGGCACTGGTGCTG-3' (reverse) }\end{array}$ \\
\hline MUC5B & $\begin{array}{l}\text { 5'-CTGCGAGACCGAGGTCAACATC-3' (forward) } \\
\text { 5'-TGGGCAGCAGGAGCACGGAG-3' (reverse) }\end{array}$ \\
\hline MUC6 & $\begin{array}{l}\text { 5'-TCACCTATCACCACACAAC-3' (forward) } \\
\text { 5'-GGAGAAGAAGGAAAAAGAG-3' (reverse) }\end{array}$ \\
\hline MUC7 & $\begin{array}{l}\text { 5'-CCACACCTAATTCTTCCC-3' (forward) } \\
\text { 5'-CTATTGCTCCACCATGTC-3' (reverse) }\end{array}$ \\
\hline MUC8 & $\begin{array}{l}\text { 5'-ACAGGGTTTCTCCTCATTG-3' (forward) } \\
\text { 5'-CGTTTATTCCAGCACTGT-3' (reverse) }\end{array}$ \\
\hline$\beta$-actin & $\begin{array}{l}\text { 5'-TTCTACAATGAGCTGCGTGTGGCT-3' (forward) } \\
\text { 5'-GCTTCTCCTTAATGTCACGCACGA-3' (reverse) }\end{array}$ \\
\hline
\end{tabular}


의 경우 $94^{\circ} \mathrm{C}$ 에서 30 초, $55^{\circ} \mathrm{C}$ 에서 30 초, $72^{\circ} \mathrm{C}$ 에서 30 초 간을 32 회, $\mathrm{MUC} 6$ 는 $94^{\circ} \mathrm{C}$ 에서 30 초, $60^{\circ} \mathrm{C}$ 에서 60 초, $72^{\circ} \mathrm{C}$ 에서 60 초간을 30 회, $\mathrm{MUC7}$ 은 $94^{\circ} \mathrm{C}$ 에서 30 초, $58^{\circ} \mathrm{C}$ 에서 1 분, $72^{\circ} \mathrm{C}$ 에서 50 초간을 34 회, $\mathrm{MUC} 8$ 은 $94^{\circ} \mathrm{C}$ 에서 30 초, $55^{\circ} \mathrm{C}$ 에서 1 분, $72^{\circ} \mathrm{C}$ 에서 1 분간을 33 회 $\beta$-actin은 $94^{\circ} \mathrm{C}$ 에서 20 초, $60^{\circ} \mathrm{C}$ 에서 50 초, $72^{\circ} \mathrm{C}$ 에서 50 초간을 32 회 시 행하고 $72^{\circ} \mathrm{C}$ 에서 10 분간 시행하였다. $\mathrm{PCR}$ 산물은 $50 \mathrm{ng} /$ $\mathrm{mL}$ 의 ethidium bromide가 들어있는 $1 \%$ Tris-boric acidethylenediaminetetraacetic acid 완충용매에서 $2 \%$ agarose gel을 통한 전기영동을 이용하고 band는 densitometry (Eagle sight software, Stratagene, CA) 를 이용하 여 분석하였다.

\section{통계처리}

실험결과는 Mann-Whitney U test를 이용하여 유의성 을 검증하였다. 통계프로그램은 SPSS 12.0 (Chicago, IL, $\mathrm{USA}$ )을 사용하였고 $p$ 값이 0.05 미만인 경우를 유의한 것으로 정하였다.

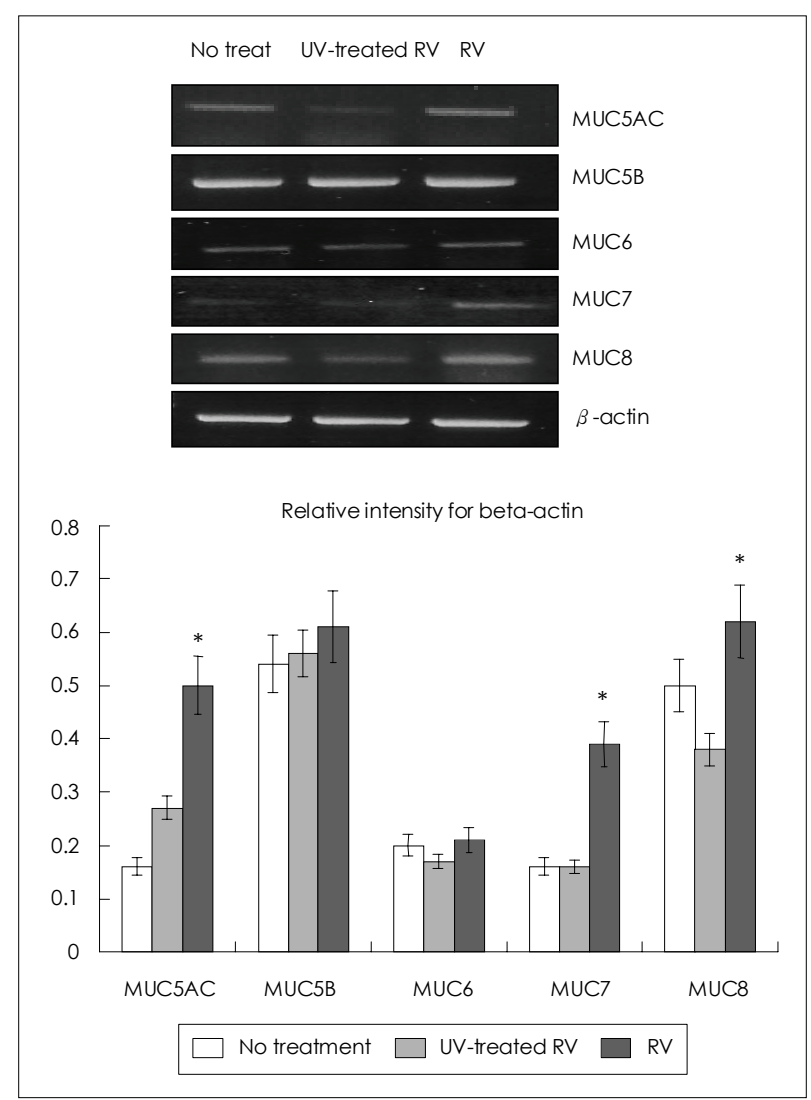

Fig. 1. Rhinovirus-induced MUC mRNA expressions. Rhinovirus significantly increased the expression of MUC5AC, MUC7, and MUC8 mRNA, but it did not affect the expression of MUC5B and MUC6 mRNA. * $p<0.05$. UV: ultraviolet, RV: Rhinovirus, mRNA: messenger ribonucleic acid.

\section{결 과}

Rhinovirus 감염 시 A549 cell에서 MUC5AC mRNA 의 발현은 inactivated rhinovirus에 비하여 약 1.85 배 가 량 증가하였고 $(p<0.05), \mathrm{MUC7}$ mRNA의 발현도 inactivated rhinovirus에 비하여 약 2.43 배 가량 증가하였으며 $(p<0.05), \mathrm{MUC} 8 \mathrm{mRNA}$ 는 inactivated rhinovirus 에 비 하여 약 1.63 배 가량 강한 발현을 $(p<0.05)$ 보였다. MUC5B, MUC6 mRNA는 발현의 증가가 관찰되지 않았다(Fig. 1).

\section{고 찰}

사람에서 발견된 20가지의 점소 유전자는 막 결합 점소 (membrane-bound mucins) 인 MUC1, MUC3, MUC4, MUC11, MUC12, MUC17, MUC18, MUC20과 겔 형성 점소(gel-forming mucins)인 MUC2, MUC5AC, MUC5B, MUC6, MUC7, MUC8, MUC9, MUC19가 있다. ${ }^{12)}$ 막 결 합 점소는 점액의 당질화 부위가 균의 리간드와 결합하여 세 균증식, 세포보호, 점막 상피의 세포증식, 종양의 침범, 전 이에 관여하고, ${ }^{13)}$ 겔 형성 점소는 점막 상피의 표면으로부 터 분비되어 점액을 형성하여 상피를 보호하고 감염물질의 침입을 방지한다. ${ }^{14)}$

본 연구에서는 기도상피세포에서 rhinovirus 처치 후 주 요 겔 형성 점소인 MUC5AC, MUC5B, MUC6, MUC7, $\mathrm{MUC8}$ 의 유전자 발현에 대하여 알아보았다. 불활성군에는 자외선 처리를 한 rhinovirus를 처치하였고 실험군에는 자 외선 처리를 하지 않은 rhinovirus를 처치하였다. MUC5AC, $\mathrm{MUC7}, \mathrm{MUC8}$ 유전자가 대조군에 비하여 실험군에서 약 1.6 2.5배 발현이 증가하였다. RT-PCR은 반 정량적인 검사로 발현이 증가한 것만을 나타낼뿐 정량적인 검사를 위해서는 real-time RT-PCR을 하여야 하나 real-time $\mathrm{RT}-\mathrm{PCR}$ 에 비하여 과정이 비교적 간단하고 검사당 비용이 적어 더 흔하게 사용되고 있다.

$\mathrm{MUC5AC}$ 와 MUC5B는 인간기도에서 분비되는 점액의 대부분을 구성하고 있다. ${ }^{14,15)}$ 그러므로 이번 연구에서 MUC$5 \mathrm{AC}$ 유전자 발현이 증가한 것은 전체적인 점액분비가 rhinovirus에 의하여 증가할 가능성이 있다는 의미이다. MUC$5 \mathrm{AC}$ 점액은 사람기관지조직과 사람기관지세포에서 rhinovirus 감염 3시간 후보다 20시간 후에 더욱 증가하였다. ${ }^{16)}$ 본 연구와 다른 점은 점액유전자가 아닌 배양액 내 점액을 측정하였고 대조군으로 불활성화 rhinovirus가 아닌 바이 러스 처치 전 배양을 사용하였다. 실험에서 rhinovirus와 함 께 처치하는 용매나 다른 물질의 영향으로 점액유전자 발 
현이나 점액분비에 영향을 줄 수 있기 때문에 불활성화 rhinovirus 처치를 대조군으로 하는 것이 바람직하다. 또한 감 기 바이러스 처치 후 기존에 존재하던 점액이 바로 분비되 는 양과 새로 만들어져 세포 밖으로 분비되는 것, 세포 안에 남아있는 점액 등이 있으므로 점액을 측정하려면 이 모두를 측정하는 것이 바람직하다. 다른 연구에서 rhinovirus -14 를 이용하여 사람기관상피세포와 점막하선세포에서 점액유 전자를 측정하였을 때 MUC5AC, MUC5B, MUC6 유전자 가 기관상피세포에서 증가하였고 점막하선세포에서는 MUC$5 \mathrm{AC}, \mathrm{MUC5B}, \mathrm{MUC7}$ 유전자가 증가하였으며 이러한 발 현증가는 처치 후 4 시간에 가장 현저하였고 24 시간에는 별 다른 차이가 없었다. ${ }^{17)}$ 본 연구의 결과와 다른 이유로는 rhinovirus형이 본 연구에서는 16형이었고 이전 연구는 14 형이었던 점을 들 수 있겠다. 다른 연구 ${ }^{16)}$ 와 비교해보면 같 은 사람기관세포배양을 이용하였으나 rhinovirus의 형이 16 형이었던 경우에는 20시간 이후에 MUC5AC 유전자가 증가하였던 반면에 14 형이었던 경우는 24 시간 후에 발현 증가가 관찰되지 않았다. 본 연구도 16 형을 사용하였고 24 시간에 발현증가가 관찰된 것으로 보아 바이러스의 형이 영향을 주었을 가능성이 있다. 또한 처치 시간도 14형을 이 용한 연구에서는 1 시간 처치 후 세척하였고 본 연구에서는 4 시간 처치 후 세척하였으며 16 형을 이용한 다른 연구 ${ }^{16)}$ 에 서는 20시간 동안 계속 바이러스 처치를 하였으므로 처치 시간에 따른 차이일 가능성도 있다.

MUC8 유전자는 비용상피세포에서 과발현되고 ${ }^{18)}$ 배양된 정상 기도 상피세포에서 감염에 의해 가장 많이 발현 조절 을 받는 점액유전자이다. ${ }^{19)}$ 따라서 rhinovirus에 의한 MUC8 유전자 발현의 증가는 점액유전자의 방어기전 중 하나로 기 도에 침입하는 바이러스로부터 물리적 방어벽을 형성하고 기도상피를 보호하는 역할을 함을 의미한다.

이러한 점액유전자 발현 증가의 기전으로 rhinovirus 감 염 후 분비세포의 분화 및 세포증식, 기도상피세포에서의 싸이토카인 분비, 염증세포 모집, $\mathrm{NF}-\mathrm{kB}$ (nuclear factor kappa-light-chain-enhancer of activated B cells) 등 의 신호전달 과정 등이 있을 수 있으나 이에 대하여는 향후 추가연구가 필요하다. 또한 점액유전자 발현 증가가 방어 기전의 일부로 코감기 증상이나 rhinovirus의 복제 등을 막고 기도상피의 손상을 적게 하는 역할을 하는 지 아니면 코감기 증상을 악화시키고 회복에 방해가 되는 지에 대해서 도 추가연구가 필요하다. 코감기에 걸린 경우 점액유전자 발현 증가가 개체에 불리하게 작용한다면 점액유전자의 발 현을 억제하는 것이 치료에 도움이 될 가능성이 있겠다.

\section{Acknowledgments}

This study was supported by Asan Institute for Life Sciences grant 2005-354.

\section{REFERENCES}

1) Yamaya M, Sasaki H. Rhinovirus and asthma. Viral Immunol 2003; 16(2):99-109.

2) Osur SL. Viral respiratory infections in association with asthma and sinusitis: a review. Ann Allergy Asthma Immunol 2002;89 (6) :553-60.

3) Gern JE. Rhinovirus respiratory infections and asthma. Am J Med 2002;112 Suppl 6A:19S-27S.

4) Yuta A, Doyle WJ, Gaumond E, Ali M, Tamarkin L, Baraniuk JN, et al. Rhinovirus infection induces mucus hypersecretion. Am J Physiol 1998;274 (6 Pt 1):L1017-23.

5) Kaliner M, Shelhamer JH, Borson B, Nadel J, Patow C, Marom Z. Human respiratory mucus. Am Rev Respir Dis 1986;134 (3) :612-21.

6) Litt M, Khan MA, Chakrin LW, Wardell JR Jr, Christian P. The viscoelasticity of fractionated canine tracheal mucus. Biorheology 1974;11 (2):111-7.

7) Rose MC, Gendler SJ. Airway mucin genes and gene products. In: Rogers D, Lethem M, editors. Airway Mucus: basic Mechanisms and Clinical Perspectives. Basel, Switzerland: Birkhauser Publishing Limitied;1997. p.41-66.

8) Voynow JA, Rose MC. Quantitation of mucin mRNA in respiratory and intestinal epithelial cells. Am J Respir Cell Mol Biol 1994;11 (6): 742-50.

9) Aust MR, Madsen CS, Jennings A, Kasperbauer JL, Gendler SJ. Mucin mRNA expression in normal and vasomotor inferior turbinates. Am J Rhinol 1997;11 (4) :293-302.

10) Audie JP, Janin A, Porchet N, Copin MC, Gosselin B, Aubert JP. Expression of human mucin genes in respiratory, digestive and reproductive tracts ascertained by in situ hybridization. J Histochem Cytochem 1993;41 (10):1479-85.

11) Berger JT, Voynow JA, Peters KW, Rose MC. Respiratiory carcinoma cell lines. MUC genes and glycoconjugates. Am J Respir Cell Mol Biol 1999;20 (3) :500-10.

12) Lillehoj ER, Kim KC. Airway mucus: its components and function. Arch Pharm Res 2002;25 (6):770-80.

13) Moniaux N, Escande F, Porchet N, Aubert JP, Bartra SK. Structural organization and classification of the human mucin genes. Front Biosci 2001;6:D1192-206.

14) Williams SJ, Wreschner DH, Tran M, Eyre HJ, Surtherland GR, McGuckin MA. MUC13, a novel human cell surface mucin expressed by epithelial and hemopoietic cells. J Biol Chem 2001;276 (21):18327-36.

15) Thornton DJ, Howard M, Khan N, Sheehan JK. Identification of two glycoforms of the MUC5B mucin in human respiratory mucus. Evidence for a cysteine-rich sequence repeated within the molecule. J Biol Chem 1997;272 (14):9561-6.

16) He SH, Zheng J, Duan MK. Induction of mucin secretion from human bronchial tissue and epithelial cells by rhinovirus and lipopolysaccharide. Acta Pharmacol Sin 2004;25 (9):1176-81.

17) Inoue $D$, Yamaya $M$, Kubo H, Sasaki T, Hosoda M, Numasaki M, et al Mechanisms of mucin production by rhinovirus infection in cultured human airway epithelial cells. Respir Physiol Neurobiol 2006;154 (3) :484-99.

18) Kim SS, Kim KS, Lee JG, Park IY, Koo JS, Yoon JH. Levels of intracellular protein and messenger RNA of mucin and lysozyme in normal human nasal and polyp epithelium. Laryngoscope 2000;110 (2 Pt 1) :276-80.

19) Yoon JH, Kim KS, Him HU, Linton JA, Lee JG. Effects of TNF-alpha and IL-1 beta on mucin, lysozyme, IL- 6 and IL- 8 in passage-2 normal human nasal epithelial cells. Acta Otolaryngol 1999;119(8): 905-10. 